\title{
The first international conference
}

\section{on Japanese information}

\author{
By Sachié Noguchi \\ Assistant Japanese Librarian \\ University of Illinois at Urbana-Champaign
}

\section{A landmark meeting at the University of Warwick, September 1-4, 1987.}

apanese achievements in business, industry, and technology have alerted Western countries to the necessity of monitoring Japanese information more closely and efficiently. Growing awareness of this has been demonstrated in both Europe and North America - in the United States, for example, by the 1983 Congressional hearing leading up to the 1988 Japanese Technical Literature Act. Although Japan stepped up its efforts to supply means of access to Japanese information more easily to overseas users, there are still problems, in particular the language barrier.

The British Library organized a timely international conference on Japanese information from September 1-4, 1987. It focused on science, technology, and commerce aiming: 1) to review existing information, problems, and solutions in accessing it; and 2) to identify trends, outstanding problems, and possible solutions, with emphasis on international cooperation.

The conference took place at the University of Warwick under the banner of the British Library Japanese Information Service and the University of Warwick Japanese Business Policy Service, supported by the United States National Technical Information Service (NTIS), the Japan Information Center of Science and Technology (JICST), and the Japan Travel Bureau. It was attended by about two hundred delegates from sixteen countries, of which $60 \%$ came from Europe (UK, Germany, Finland, Netherlands, France, Sweden, Austria, Switzerland, Belgium, Denmark), $20 \%$ from America, and $17 \%$ from Japan. The delegates represented universities, research institutions, industries, information agencies, government offices, and international bodies.

The four-day meeting was opened by Lord Quinton, chairman of the British Library. There were eleven sessions-background, U.S. policy, patterns of publication, research and collaboration, the Japanese language, language solutions, Japanese online sources, European sources, special sector needs, special sources, and more special sources-and two sessions of special delegates spots, video and talk. The final panel discussion was chaired by R.J. Samuels of the MIT Japan Science and Technology Program. The full paper preprints were prepared and distributed at the time of registration and short oral presentations highlighting the most important points were given at the conference. Exhibitions and advertisements by more than thirty book dealers or information vendors were also featured, including transcontinental online demonstrations.

Among about forty U.S. participants, sixteen presented papers for eight different sessions and five served as session chairs. In the U.S. policy session, chaired by D.B. Shonyo of the National Tech- 


\section{ACQUISITION PERSPECTIVES}

5. Monographs in continuation and standing orders are given special attention. Your first volume required and all future volumes will be delivered as soon as they become available.

Write or call for details about our reliable standing order service to libraries.

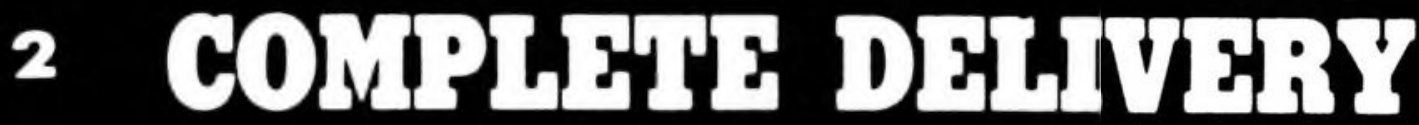

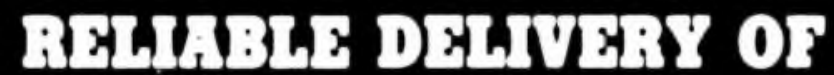
BEQULAD ITHWS

\section{BOOK HOUSE}

\section{SIPTDNO}

\section{ORDHAS}

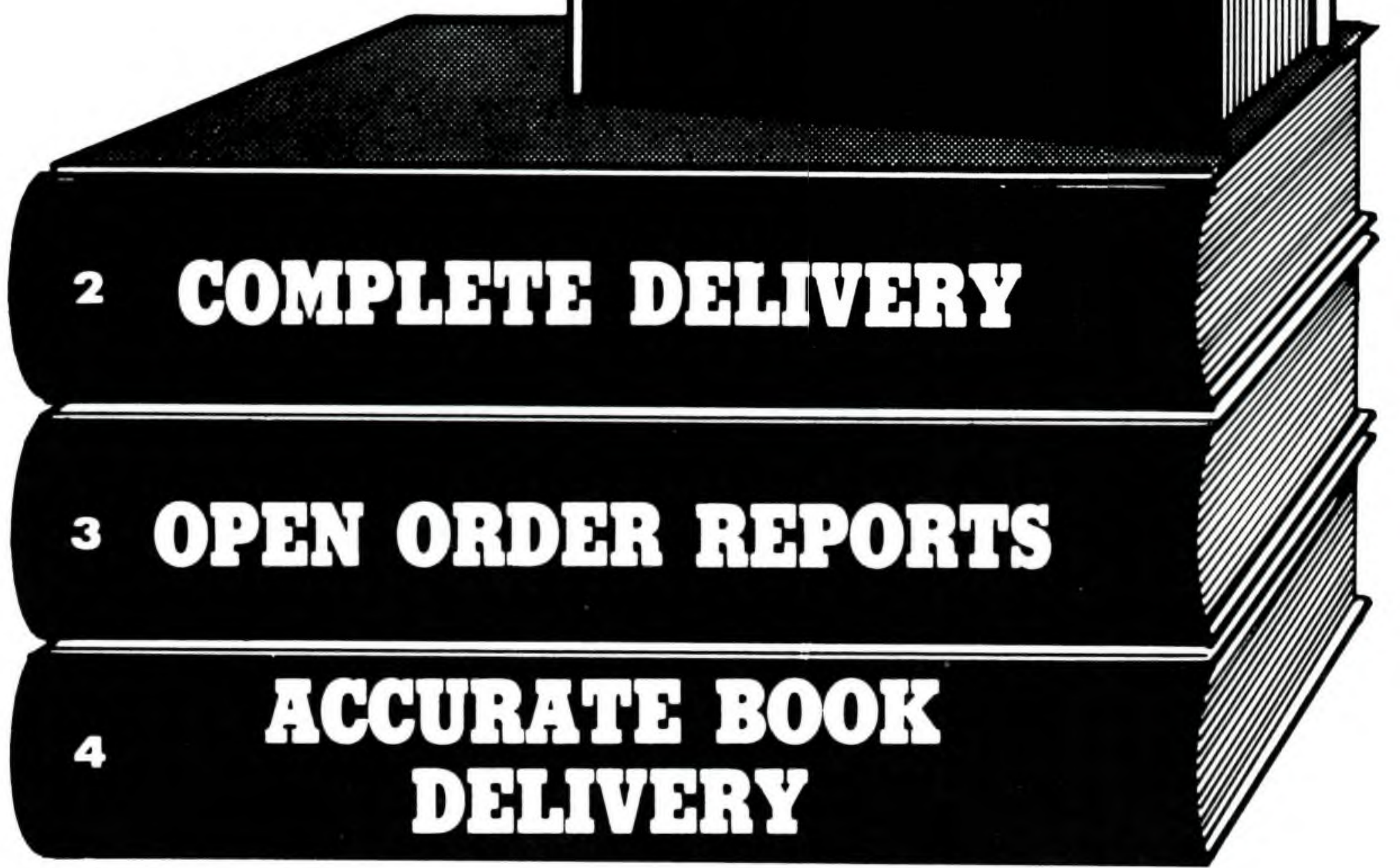

CALL TOLL-FREE TODAY

1-800-248-1146

In Canada \& Michigan

CALL COLLECT (517) 849-2117

OCLC Vendor No. 17397

SAN 169-3859 the

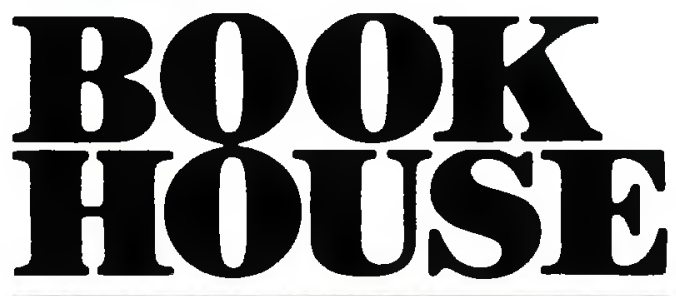

JOBBERS SERVING LIBRARIES WITH ANY BOOK IN PRINT SINCE 1962 2C8 WEST CHICAGO STREET JONESVILLE, MICHIGAN 49250 
nical Information Service (NTIS), R.J. Samuels spoke on "Japanese Scientific and Technological Information in the United States: Public Policy and Private Initiatives," followed by J.A. Alic, U.S. Office of Technology Assessment, summing up "Japanese Science and Technology: Some Recent Efforts in the United States to Improve Monitoring" as a preview for N.R. Miller of LC's Congressional Research Service, whose presentation was titled "Japanese R \& D and U.S. Technology Policy."

S.K. Coleman, North Carolina Japan Center, North Carolina State University, presented a video, "Coming of Age: A New American Approach to Japanese Science and Technology," and gave a talk on "The University Role in Gaining Access to Japanese Scientific and Technical Information." Delegates from university libraries also presented papers: I.T. Morita, "Information Flow in Japan: Some Characteristics," and M.H. Donovan, "Mini Communications," both from Ohio State University; T.F. Welch, director of libraries at Northern Illinois University, "U.S.Japan Bi-national Conferences on Libraries in Higher Education: A Review of the Issues"; M. Williams, "Characteristics and Evaluation of Japanese Life Science Serials," E.B Davis, "Information Services in Biotechnologically Active Research Organizations in Japan and the United States," and S. Noguchi, "Literature on "Japanese-Style Management: The Citing of Publications in Western Language Materials, Problems and Some Possible Solutions," from the University of Illinois at Urbana-Champaign.

During the conference a wide range of activities were reported and discussed. At the final session special remarks were made on the accessibility of grey literature, preparation of a directory of people working in the field, information utility for nonpaper textual materials, the need to expand services beyond JICST, and so on. To wrap up the meeting, the topic of "what to talk about at the next conference; where should we go from here?" was discussed and the following issues were suggested: intergovernmental support, training of Japanese specialists, translation experts, communication among scientists, dissemination and synthesization of information, technology transfer, deregulation of telecommunications, intellectual property protection, and end-users.

The Conference provided the first opportunity to bring people active and interested in the field together to discuss activities, ideas, and problems, and to seek solutions. The efforts of the two British Library organizers, S.V. King and G.J. Sassoon, were very much appreciated, and the aims of the conference will be extended in the future.
12 Lunar Drive/Drawer $A B$ Woodbridge, CT 06525 Toll-free: 1-800-PEACH-RP TWX: 710-465-6345 FAX: 203-397-3893

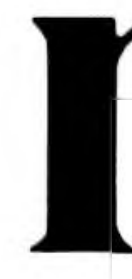

\section{Two hundred historic years of The World's news in microform.}

Over 200 years of factual reporting . . . dozens of acclaimed international newspapers like The Times, The Washington Post, Le Monde, Der Spiegel, Asahi Shimbun, The Age, Financial Times, Jewish Chronicle ... all of them available on microfilm from Research Publications.

This is probably the most inexhaustible, highquality collection of international newspapers ever preserved in microform - perfect for scholars, researchers, and the general public.

For further information, or to order current subscriptions and backfiles, call Research Publications today at 1-800-REACH-RP (1-800-732-2477). From Connecticut, Alaska and Canada, call collect 203-397-2600.

research publications ${ }^{\circledR}$ 